\title{
Outer-rise normal fault development and influence on near-trench décollement propagation along the Japan Trench, off Tohoku
}

\author{
Brian Boston ${ }^{1 *}$, Gregory F Moore ${ }^{1}$, Yasuyuki Nakamura ${ }^{2}$ and Shuichi Kodaira ${ }^{2}$
}

\begin{abstract}
Multichannel seismic reflection lines image the subducting Pacific Plate to approximately $75 \mathrm{~km}$ seaward of the Japan Trench and document the incoming plate sediment, faults, and deformation front near the 2011 Tohoku earthquake epicenter. Sediment thickness of the incoming plate varies from $<50$ to $>600 \mathrm{~m}$ with evidence of slumping near normal faults. We find recent sediment deposits in normal fault footwalls and topographic lows. We studied the development of two different classes of normal faults: faults that offset the igneous basement and faults restricted to the sediment section. Faults that cut the basement seaward of the Japan Trench also offset the seafloor and are therefore able to be well characterized from multiple bathymetric surveys. Images of 199 basement-cutting faults reveal an average throw of approximately $120 \mathrm{~m}$ and average fault spacing of approximately $2 \mathrm{~km}$. Faults within the sediment column are poorly documented and exhibit offsets of approximately $20 \mathrm{~m}$, with densely spaced populations near the trench axis. Regional seismic lines show lateral variations in location of the Japan Trench deformation front throughout the region, documenting the incoming plate's influence on the deformation front's location. Where horst blocks are carried into the trench, seaward propagation of the deformation front is diminished compared to areas where a graben has entered the trench. We propose that the décollement's propagation into the trench graben may be influenced by local stress changes or displacements due to subduction of active normal faults. The location and geometry of the up-dip décollement at the Japan Trench is potentially controlled by the incoming outer-rise faults.
\end{abstract}

Keywords: Japan Trench; Subduction; Normal faults; Outer rise; Trench; Oceanic plate

\section{Background}

When large bathymetric features, such as seamounts, fracture zones, ridges, and oceanic plateaus, are subducted at convergent margins, they strongly deform the landward trench slopes (e.g., McCann and Sykes 1984; Lallemand and Le Pichon 1987; Dominguez et al. 1998; Taylor et al. 2005). Smaller features, such as subducting horst and graben structures, were once considered to play a role in sediment subduction and upper plate abrasion by horst blocks (Hilde 1983), but better imaging of the subducting plate suggested the subduction plane was well above the top of such features (von Huene and Culotta 1989). Sediment thickness and lithostratigraphy of the incoming

\footnotetext{
* Correspondence: bboston@hawaii.edu

'Department of Geology and Geophysics, University of Hawai'i at Mānoa, 1680 East-West Road, Honolulu, HI 96822, USA

Full list of author information is available at the end of the article
}

plate may further influence the landward trench slope by controlling the physical properties of the margin and inducing lateral heterogeneities in prism formation (Underwood 2007; Ike et al. 2008). Although large-scale features can dominate the upper plate morphology, small-scale features are likely more common at most trenches and may also play a role in modifying the upper plate over time.

Normal faults, found on the outer rise of many Pacific trenches (e.g., Masson 1991), are one type of small-scale feature with potential impacts on the upper plate morphology. As the plate enters a subduction zone, flexural bending of the plate produces the outer rise (e.g., Bodine et al. 1981). Brittle failure manifested by normal faults permanently deforms the surface of the downgoing plate. Faults can form parallel to the trench axis in subduction zones. However, in regions where the abyssal hill fabric, formed at oceanic spreading centers, strikes at a low angle 
$\left(<25^{\circ}\right.$ to $\left.30^{\circ}\right)$ to the trench, the abyssal hill faults are reactivated instead of forming new faults (Masson 1991). Reactivated abyssal hill faults are identified by their strike, which is parallel to the abyssal hill fabric or magnetic lineations seaward of the trench (Billen et al. 2007). Flexural bending structures and seafloor spreading fabrics along the outer rise are the major contributors to strikes of incoming topographic features on the Northwestern Pacific Plate (Nakanishi 2011). Furthermore, normal faults produced by plate flexure seaward of the trench penetrate into the mantle are thought to allow hydration of the upper mantle and crust (Ranero et al. 2003; Grevemeyer et al. 2007) leading to a potential role in overpressuring and hydrofracturing of the upper plate at depth (von Huene et al. 2004).

The dominant features observed on the incoming Pacific Plate are bending-related normal faults, abyssal hill fabric, fracture zones, seamounts, and elongated ridges (Nakanishi 2011). The incoming outer-rise faults are largely active structures before and during subduction. Following a large megathrust earthquake at a subduction zone, shallow intraplate earthquakes are often detected along the outer rise (Christensen and Ruff 1988); these earthquakes might be caused by the Coulomb stress change from the main thrust event (e.g., Sato et al. 2013). After the $2011 \mathrm{Mw} 9.0$ Tohoku earthquake, the outer rise of the Japan Trench was dominated by normal fault earthquakes of varying size, depth, and spatial location. These earthquakes may still be potential tsunamigenic hazards, as several Mw $>7.0$ events have occurred since the main shock, including a large outer-rise event of $\mathrm{Mw}$ 7.7 (Lay et al. 2011) and two Mw 7.2 earthquakes in 2012 (Obana et al. 2014). Historically, large outer-rise events within this region include the $2005 \mathrm{Mw} 7.0$ (Hino et al. 2009) and the $1933 \mathrm{Mw} 8.4$ (Kanamori 1971) events. Precise measurements from ocean bottom seismographs (OBSs) detected numerous intraplate earthquakes after the 2011 event ranging in location from approximately $120 \mathrm{~km}$ seaward of the trench to approximately $90 \mathrm{~km}$ landward of the trench with mainly normal fault focal mechanisms in the uppermost subducting Pacific Plate (Obana et al. 2012; Obana et al. 2013).

Geophysical analysis of the Tohoku earthquake revealed large coseismic slip that extended to the trench (Ide et al. 2011; Ito et al. 2011; Fujiwara et al. 2011; Fujii et al. 2011). Differential bathymetry from before and after the earthquake also revealed the largest vertical displacements near the trench axis (Fujiwara et al. 2011), and seismic reflection data imaged frontal thrust development after the event (Kodaira et al. 2012). Seismic data collected in 2011 suggested that the décollement steps down into a local graben at the trench axis (Kodaira et al. 2012; Nakamura et al. 2013) rather than remaining at a constant depth above the overriding plate and 'bulldozing' the sediment from the top of the incoming horst blocks (e.g., Hilde 1983). Subduction of active bending-related normal faults may have larger implications for deformation of the near-trench upper plate and may be a small contributor to tsunamigenesis, with large seafloor displacements but small areal extent. To better determine the role of the incoming plate on near-trench coseismic processes, we first examine the nature of the crust that is subducting at the Japan Trench.

This study focuses on the basement and sediment structure of the incoming Pacific Plate off Tohoku. We investigate the morphology of outer-rise normal fault systems and their lateral variations along the Japan Trench. These fault systems are particularly important in the Japan Trench because the lack of significant trench sediment fill means that, along many parts of the margin, the morphologic trench is defined where a graben has entered the trench. Therefore, it is important to define the characteristics of the subducting normal fault system. We use recently collected seismic reflection data seaward of the Tohoku earthquake epicenter to image the sediment and basement structure of the Pacific Plate. In the present study, we analyze the bending-related normal faults off Tohoku with a goal of establishing relationships among the subducting horst-graben structures, their sediment cover, and deformation in the Japan Trench and the adjacent landward trench slope.

\section{Methods}

We use four two-dimensional (2D) multichannel seismic (MCS) surveys carried out by the Japan Agency for Marine-Earth Science and Technology (JAMSTEC) for a total of 28 dip lines and 19 strike lines along the Japan Trench. JAMSTEC's vessel R/V Kairei conducted three MCS surveys in March, April to May, and August to September 2011, collecting a total of 15 regional lines. The seismic system used a 444-channel hydrophone streamer, 12.5-m group interval, 6,000-m-long receiver cable, with a $7,800 \mathrm{in}^{3}$ air gun array fired at $50-\mathrm{m}$ intervals, producing a common mid-point (CMP) interval of $6.25 \mathrm{~m}$. R/V Kaiyo collected 32 high-resolution seismic lines in October to November 2011. The acquisition system used a 192-channel, 6.25-m group interval, 1,200-m-long receiver cable, with a 320 in. $^{3}$ cluster gun array fired at $37.5-\mathrm{m}$ intervals. Line spacing for the Kaiyo seismic grid was approximately $500 \mathrm{~m}$ with a CMP interval of $3.125 \mathrm{~m}$. Both regional and highresolution lines were processed through conventional workflows (e.g., Yilmaz 2001) that included trace edit, CMP binning, band-pass filter, velocity analysis, normal moveout correction, and CMP stacking. We performed Kirchhoff post-stack depth migration (PoSDM) on the regional Kairei lines using previous local refraction and reflection studies (e.g., Tsuru et al. 2000) to constrain our velocity model. For the high-resolution Kaiyo lines, we performed Kirchhoff pre-stack depth migration (PSDM). Due to the 
short streamer-cable length, the velocity model for the PSDM is poorly constrained, so our starting velocity models were based on velocity values of PoSDM migrations for each line. We performed 2 to 4 iterations of velocity analyses for PSDM creating a final model that produced the clearest image. Because of the great water depths $(>6,000 \mathrm{~m})$, the water velocity (which does not vary greatly) has a large effect on the migrations. We estimate that within the sediment section, which is less than 1,000-mthick, our velocity errors are no more than approximately 200 to $400 \mathrm{~m} \mathrm{~s}^{-1}$ based on PSDM sediment velocity sensitivity in the high-resolution lines (e.g., Tsuru et al. 2000; Costa Pisani et al. 2005). Such velocity errors would result in a maximum of approximately $5 \%$ to $10 \%$ error in depth that would not affect our structural interpretations.

We combined multibeam echosounder data collected during more than 150 JAMSTEC cruises (available from the JAMSTEC DARWIN database, http://www.godac.jamstec.go.jp/darwin) to produce our bathymetry map. All of these JAMSTEC cruises used SeaBeam systems. Regions with no multibeam ship tracks are plotted with the GEBCO 30 arcsec grid (http://www.gebco.net). We applied noise reduction and merging techniques, gridding, and filtering to produce a final dataset (Figure 1). The detailed bathymetry and a computer-generated slope map delineate the surface expression of the normal faults, allowing us to map their orientations.

\section{Results}

\section{Distribution of outer-rise normal faults off Tohoku}

The bathymetric and slope maps clearly show normal faults on the Pacific Plate seaward of the Japan Trench (Figure 1). Surface breaks are detected as far as approximately $120 \mathrm{~km}$ seaward of the trench axis with the strike of the faults parallel to the trench trend. Sixty kilometers landward from the most seaward surface breaks, the fault patterns become more intricate (Figures 2 and 3), presumably a reflection of these faults' interacting with the pre-existing fabric of the Pacific Plate and each other as they propagate (e.g., Ranero et al. 2003). The preexisting fabric appears to limit certain fault orientations and promote others, as active fault strikes coincide with the orientations of fracture zones and abyssal hill fabric (Nakanishi 2011). The southeast region of the survey area is slightly more complex due to potential petite spot volcanism (Site C of Hirano et al. 2008) making it difficult to determine the strike of basement-cutting faults because of more relief in the topography and regional sediment thinning (Figure 1). Fault interactions on the incoming Pacific Plate produce a heavily deformed and spatially complex fault pattern just seaward of the trench.

The MCS data only extend approximately $75 \mathrm{~km}$ seaward of the Japan Trench but still provide insight into the beginning of faulting. Line D19 intersects both abyssal hill and trench-parallel fabrics (Figure 2). Although the geometry of line D19 is not ideal for imaging those fabrics (its line is not perpendicular to the strike of the fabrics), the seismic line does show continuous horizons above the buried abyssal hill topography, which formed at the spreading center. The continuity of reflectors over the abyssal hill implies that the fault associated with the abyssal hill either is not active or has not slipped enough to offset the youngest sediments. A few kilometers west of the abyssal hill (Figure 2B), a trench-parallel fault (green fault in Figure 2B) offsets the top of igneous crust (TIC) by approximately $30 \mathrm{~m}$. Continued propagation of faults generates three sets of fault orientations: (a) parallel to the abyssal hills, (b) parallel to fracture zones, and (c) parallel to the trench. Faults with zig-zag surface traces containing sharp bends and irregular paths develop where the faults with differing strikes intersect (Figures 1 and 3). This indicates that trench-parallel faulting may control the early stage of brittle deformation with reactivation of pre-existing structures developing later.

\section{Basement-cutting faults}

We interpreted 199 normal faults that cut the TIC within the area of the seismic data survey. Throws are based on the vertical offset of the interpreted TIC. In each seismic line, we calculate cumulative throw at the distance to the trench of each fault by summing the throws of all faults seaward of that point (Figure 4). However, the seismic lines' seaward-termination points are not constant, causing the region $>30 \mathrm{~km}$ from the trench to be undersampled. Slopes of cumulative throw for each seismic line reveal deformation per distance. Linear regression of cumulative throw versus distance, using a maximum distance of $30 \mathrm{~km}$ from the trench to reduce sampling effects, indicates that there are small differences in cumulative throw between the south, central, and north regions. For seismic line groups (south to north) D02 to D06, TH03 to D13, and D15 to D19, the median absolute value of cumulative throw slope is $2.50^{\circ}, 3.46^{\circ}$, and $3.66^{\circ}$, respectively. Maximum fault throw on a single fault is $>500 \mathrm{~m}$ but more than half of the faults have throws of $<100 \mathrm{~m}$ with the average offset being approximately $120 \mathrm{~m}$. Of the 199 faults interpreted, 105 of them dip landward, whereas 94 faults dip seaward. The median number of faults increases towards the trench (Figure 4) with variations from line to line. There is a minor drop in the number of faults at a distance of 30 to $40 \mathrm{~km}$ from the trench. This is the result of the termination of multiple seismic lines near $30 \mathrm{~km}$ to the trench, which leads to low fault counts for that distance bin. Fault spacing averages approximately $2 \mathrm{~km}$ with a minimum and maximum spacing of 200 to $10 \mathrm{~km}$. Analysis of fault throw within our survey region from available seismic (Tsuru et al. 2000) and bathymetry data (Iwabuchi 2012; 2013) is prone to two types of error: variation in sediment thickness in the region 


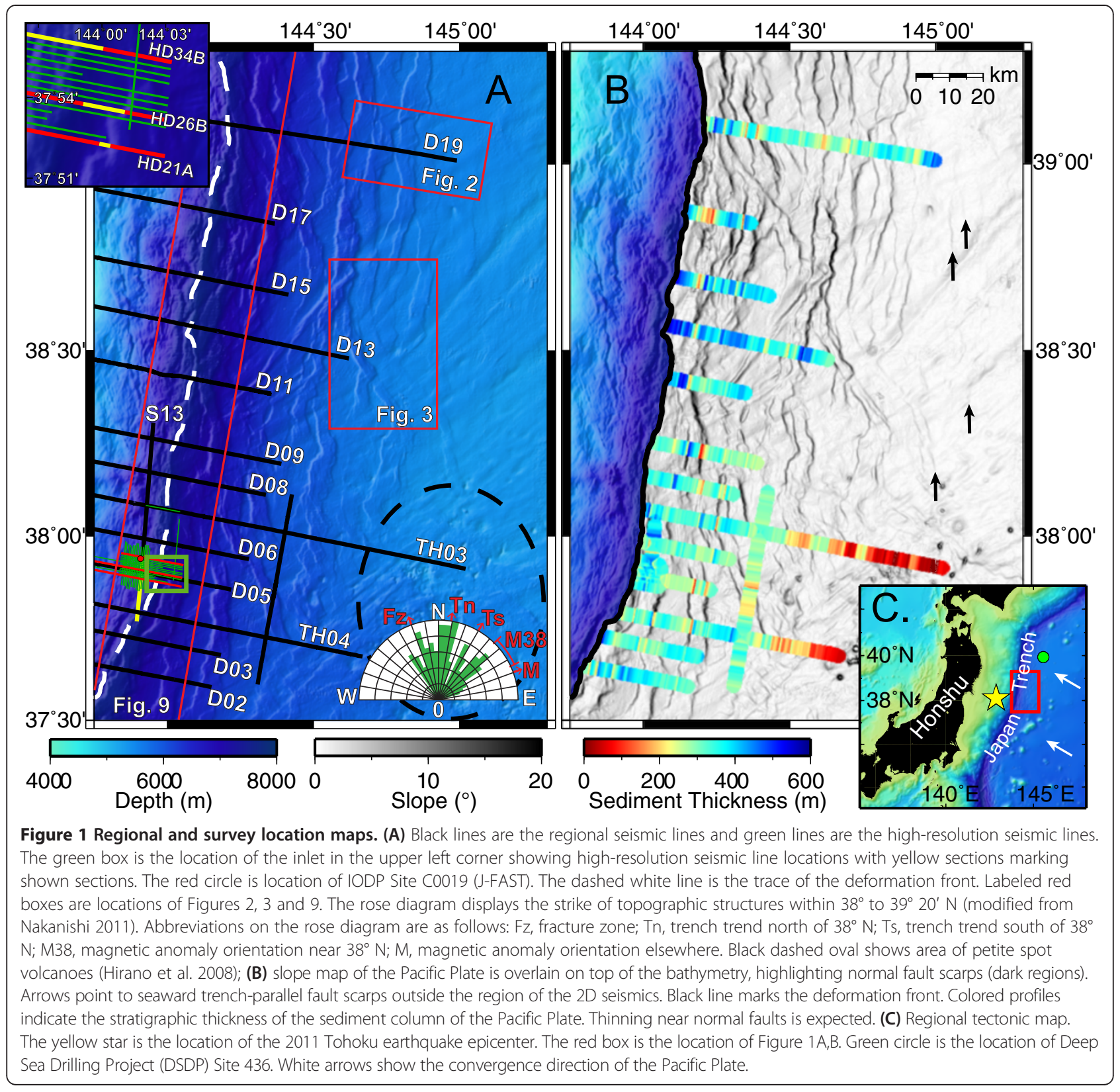

complicates the bathymetry-based analysis and limited number of pervious seismic lines in this area is insufficient to provide complete regional coverage.

\section{Incoming Pacific Plate sediments}

The Japan Trench margin has long been known for its relatively thin incoming sediment column of approximately $400 \mathrm{~m}$ from both seismic and DSDP drill cruises (e.g., Ludwig et al. 1966; Shipboard Scientific Party 1980). Our data provide new insight into regional variation in sediment thickness and internal deformation within the sediments.

\section{Sediment thickness}

We evaluated sediment thickness along a series of profiles, based on interpretations of the seafloor and TIC, using both regional and high-resolution lines to plot the stratigraphic thickness of the sediment column (Figure 1B). Thinning of the sediment section is expected above the fault surface at footwalls of normal faults (Groshong 2006) and should not be interpreted as stratigraphic thickness. We find a range of sediment thickness of 0 to $600 \mathrm{~m}$ along the incoming Pacific Plate. Thinning in the southeast is largely found near potential 'petite spot' volcanoes (Figure 1A; Site $\mathrm{C}$ of Hirano et al. 2008) and is likely related to the formation of these small cones, or to erosion around them. Elsewhere, 


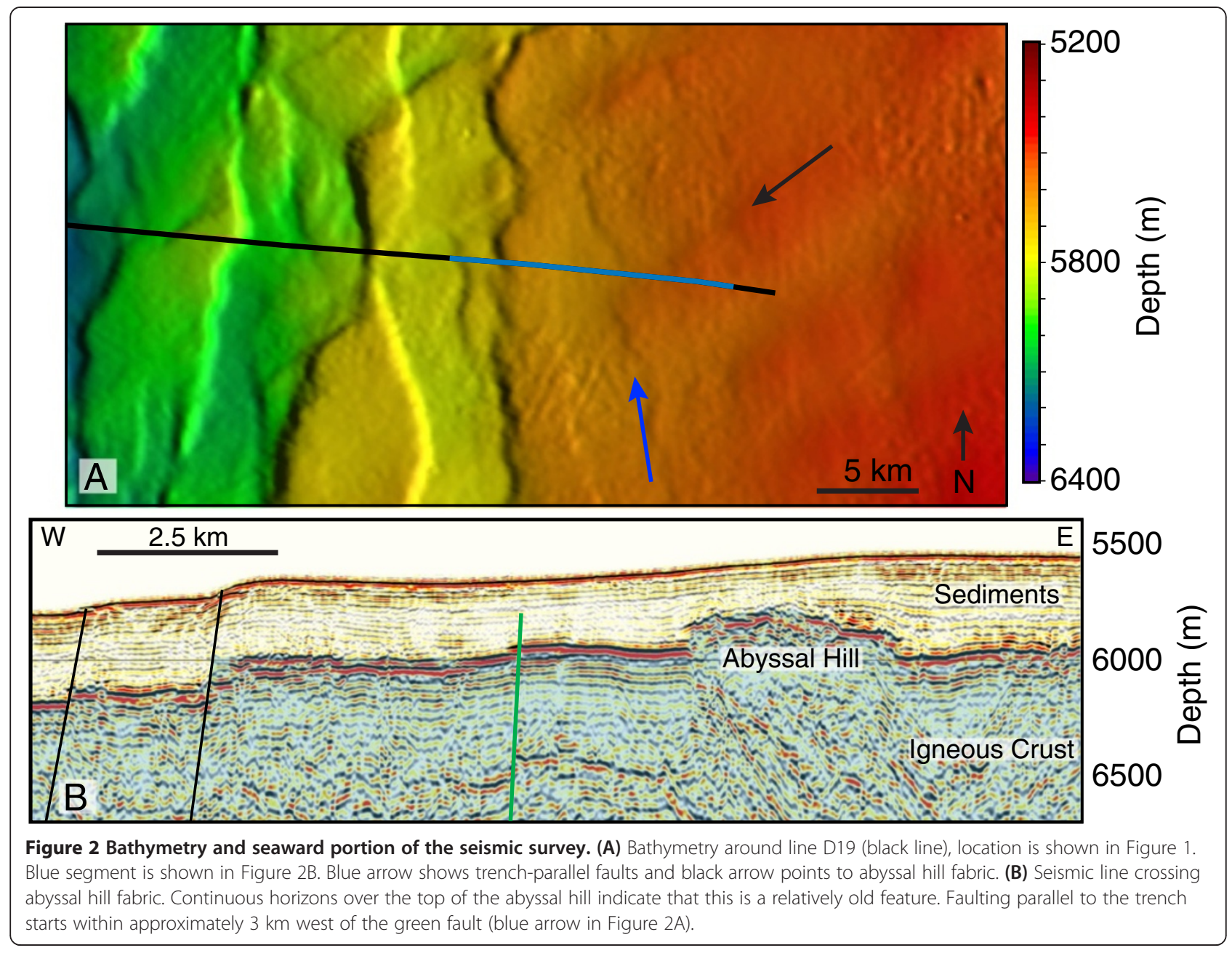

thickness is generally related to initial deposition or reworking of the sediment. Sediment thickness varies from line to line but generally of increases towards the trench.

Evidence for variation in sediment thickness and neartrench sediment deposition is found throughout the survey region. As an example, Line D02 in the southern part of the survey area (Figure 5B) illustrates the sedimentary section surrounding the trench axis. The base of the sediment column is marked as the blue dashed line, which has an apparent dip to the west. An unconformity at the top of the sediment section is discernible near the trench axis, with a near horizontal dip, and is marked with a green dashed line. This pair of markers implies that the original sediment column was tilted landward during bending of the subducting plate, followed by deposition of horizontal sediments in the trench. High-resolution line HD21A also images recent sediments that onlap older, landward-tilted strata in a developing graben adjacent to a normal fault, seaward of the trench (Figure 5C). Slight rotation of the lower horizons (in the blue region) indicates syndepositional faulting. Little faulting has occurred after this initial rotation, however, as the upper horizons are near horizontal. Seafloor displacement from this fault is small, indicating that either recent sedimentation has obscured any surface offsets or the fault currently is inactive.

\section{Near-trench, sediment-restricted faults}

Faulting and fracturing of the sediment column occurs along the outer rise. Dives with submersible Shinkai 6500 in the 1990s were the first to observe open cracks striking parallel to the horst and graben system at the outer rise of the Japan Trench (Ogawa et al. 1997). Our high-resolution seismic lines image similar structures. Lines HD26B and HD27B (500 m north of HD26B) show an incoming horst approximately $1 \mathrm{~km}$ seaward of the trench axis (Figure 6). Lithologic units were correlated from DSDP Site 436 (Shipboard Scientific Party 1980). Faults within the sediment column (units 1 and 2) exhibit offsets of approximately $20 \mathrm{~m}$ or less and are densely spaced, with populations of approximately 20 faults occurring within an approximately 2-km-long interval on Figure 6. These faults to do not appear to offset the top of the chert layer (unit 3). Unit 3 


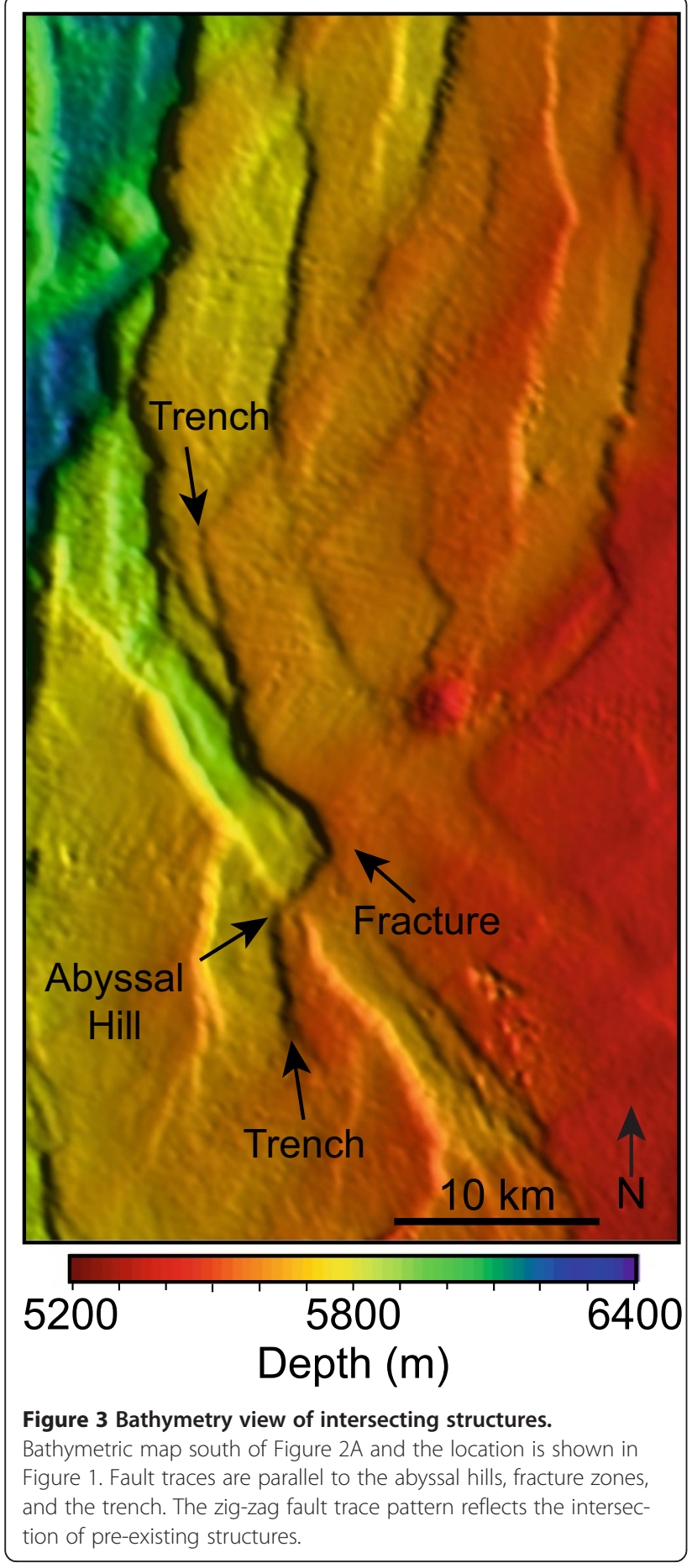

reflections are deformed internally, but the upper boundary of the unit is not disrupted. The fault pattern in unit 1 shows poor vertical fault connectivity. Faults do not appear to be confined to a specific sedimentary layer within unit 1 . Increased sediment deformation around a nearby basement-cutting fault is common. There is no evidence for growth faulting along these sediment-restricted faults, indicating that the fault system is young. Landward (westward), towards a bounding basement-cutting fault, unit 1 reflections become discontinuous, indicating that the region is heavily deformed. Unit 1 thins in this discontinuous region, potentially from slumping of material into the graben to the west.

\section{The deformation front along the Japan Trench}

Our seismic lines reveal the subduction of horst and graben systems and their interactions with the landward trench slope. We define the deformation front as the seafloor trace where either chaotic reflections of the landward slope or the frontal thrust contact coherent, continuous reflections of the incoming plate (Figures 5 and 7). We used the bathymetry grid to interpolate the deformation front between seismic lines, correlating similar topographic features identified on the seismic lines. The deformation front is better defined on the high-resolution lines, which also reveal an imbricate thrust structure in the trench (Figure 7). In many areas, the regional lines display only chaotic reflections around the imbricate thrusts due to their lower resolution.

Where a horst block is subducted beneath the base of the landward trench slope, the décollement is localized near the top of the chert layer at the top of the horst (Figure 7). At the seaward edge of the horst block, a low-angle, seaward-dipping reflection shows that the décollement drops down into the adjacent graben, where it localizes within the sediment column, approximately 10 to $20 \mathrm{~m}$ above the chert layer.

North-south profiles aid in lateral interpretation between horst-graben systems. The high-resolution lines are concentrated over a single trench-graben system. However, strike line S13 images the adjacent section to the north showing both a subducted horst and graben system beneath the landward trench slope (Figure 8). We interpret the décollement as the surface between the continuous (blue) horizons beneath and the deformed (red) horizons above the plane. Across the main part of a horst or graben, approximately $100 \mathrm{~m}$ of sediments (blue region) are subducted with minimal variations along the profile, but adjacent to the bounding normal faults, a large amount of sediment that has slumped from the adjacent horst block is being subducted. Furthermore, the seafloor appears to follow the morphology of the TIC indicating that seafloor topography is controlled by the underlying horst-graben morphology.

To investigate effects of the subducting plate on the deformation front, we plot the location of the deformation front and the underlying structures (Figure 9). The continuous bathymetric expression of the horst blocks allows us to confidently interpolate our seismic interpretations between the seismic lines. An oblique horst is currently at the deformation front in the southern region, at lines D02 and D03 (Figure 9). The distance from the trench axis to the deformation front is 


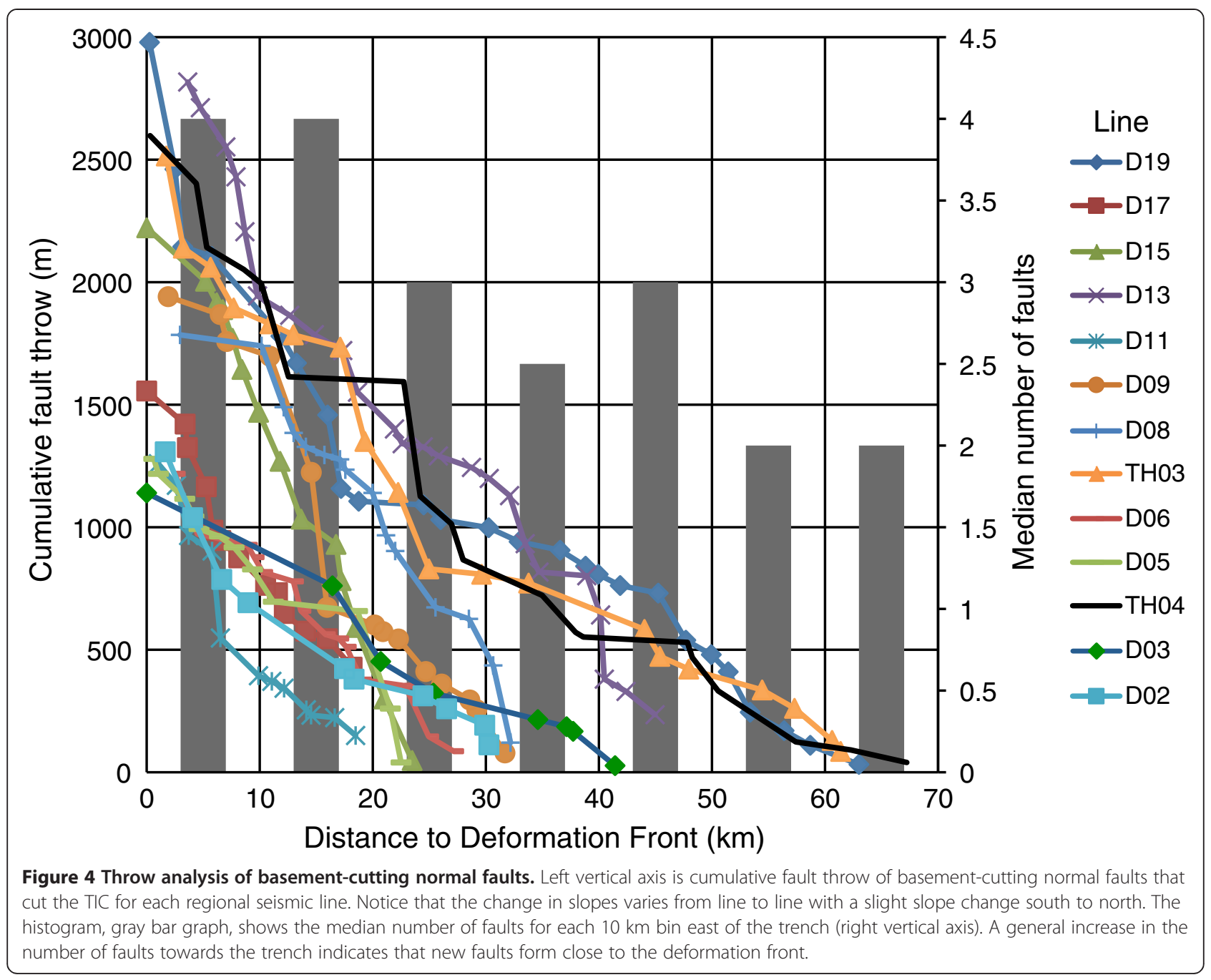

to a maximum of approximately $4 \mathrm{~km}$. At Line TH04 (Figure 9), a graben is being subducted under the deformation front (Figure 8). Here, the deformation front is located further seaward and near the trench axis. Bathymetric highs within the graben reflect the vertical growth of anticlines from the imbricate thrust faults (Figure 7). From line TH04 to D11, the deformation front is located within a graben (Figure 9). However, there is a topographic low at the deformation front at line TH03. This change in topography indicates lateral variation in the vertical growth of the thrust system within a graben, which may be related to previously subducted structures. At line D13 to D15, the deformation front is located above a horst and further west than at line D11. The deformation front at line D17 is above a half-graben (Figure 5). At the northern end of the survey, line D19, the deformation front is on the landward edge of a horst (Figure 9). We generally find that subduction of a horst temporarily impedes seaward propagation of the deformation front.

\section{Discussion}

\section{Fault development}

Earthquakes and bathymetric trends demonstrate that bending-related faults form at a maximum of approximately $120 \mathrm{~km}$ east of the Japan Trench axis (Obana et al. 2012; Nakanishi 2011). A simple subduction calculation with the Pacific Plate subducting at a rate of approximately 8 to $10 \mathrm{~cm}$ /year (DeMets et al. 2010; Apel et al. 2006; Argus et al. 2011; Niitsuma 2004) nearly orthogonally under Honshu, predicts the oldest normal faults about to be subducted to be approximately 1.2 to $1.5 \mathrm{Ma}$. Assuming steady slip on the normal faults, maximum throws of $500 \mathrm{~m}$ divided by the age of the oldest faults gives a maximum throw rate of 333 to $417 \mathrm{~m} / \mathrm{Ma}$. Faults with smaller offsets must be much younger or less active. The increase in the density of the faults westward, towards the trench, indicates that new faults continue to form as the plate nears the trench, which indicates that the assumption of steady-state deformation is incorrect. This overall pattern is similar to normal fault development in other trenches, such as the Middle America 


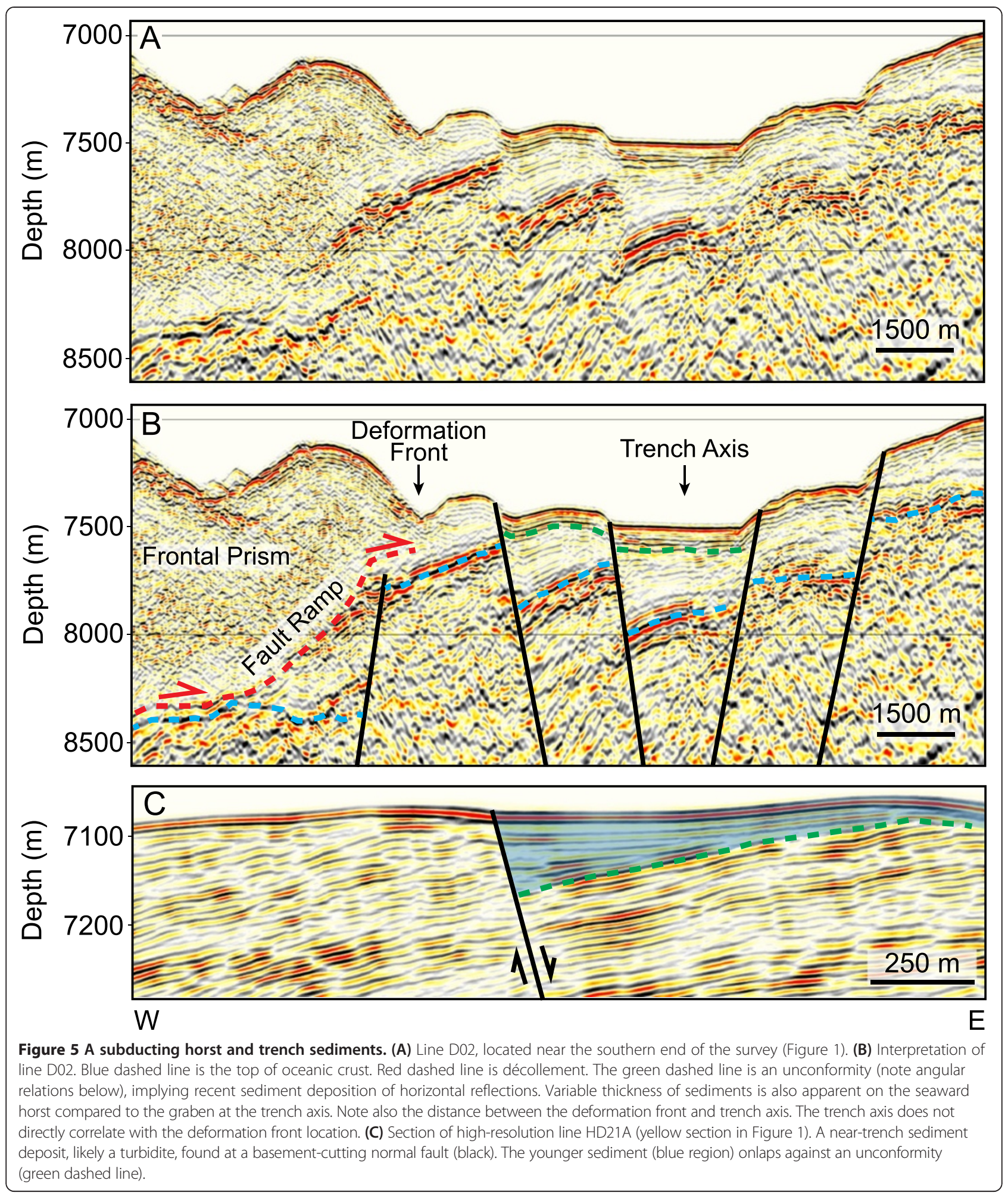

Trench (Ranero et al. 2003). Furthermore, average fault spacing of $2 \mathrm{~km}$ is on the same order as predicted in some modeling studies (Faccenda et al. 2009), although other models generate larger fault spacing of up to $10 \mathrm{~km}$ (Naliboff et al. 2013), which is the maximum fault spacing we observe.
The increase in the number of faults towards the trench and the range of fault spacing suggests continuous formation of new faults occurs as the Pacific Plate approaches the trench rather than apportioning strain to only major, more widely spaced faults. 


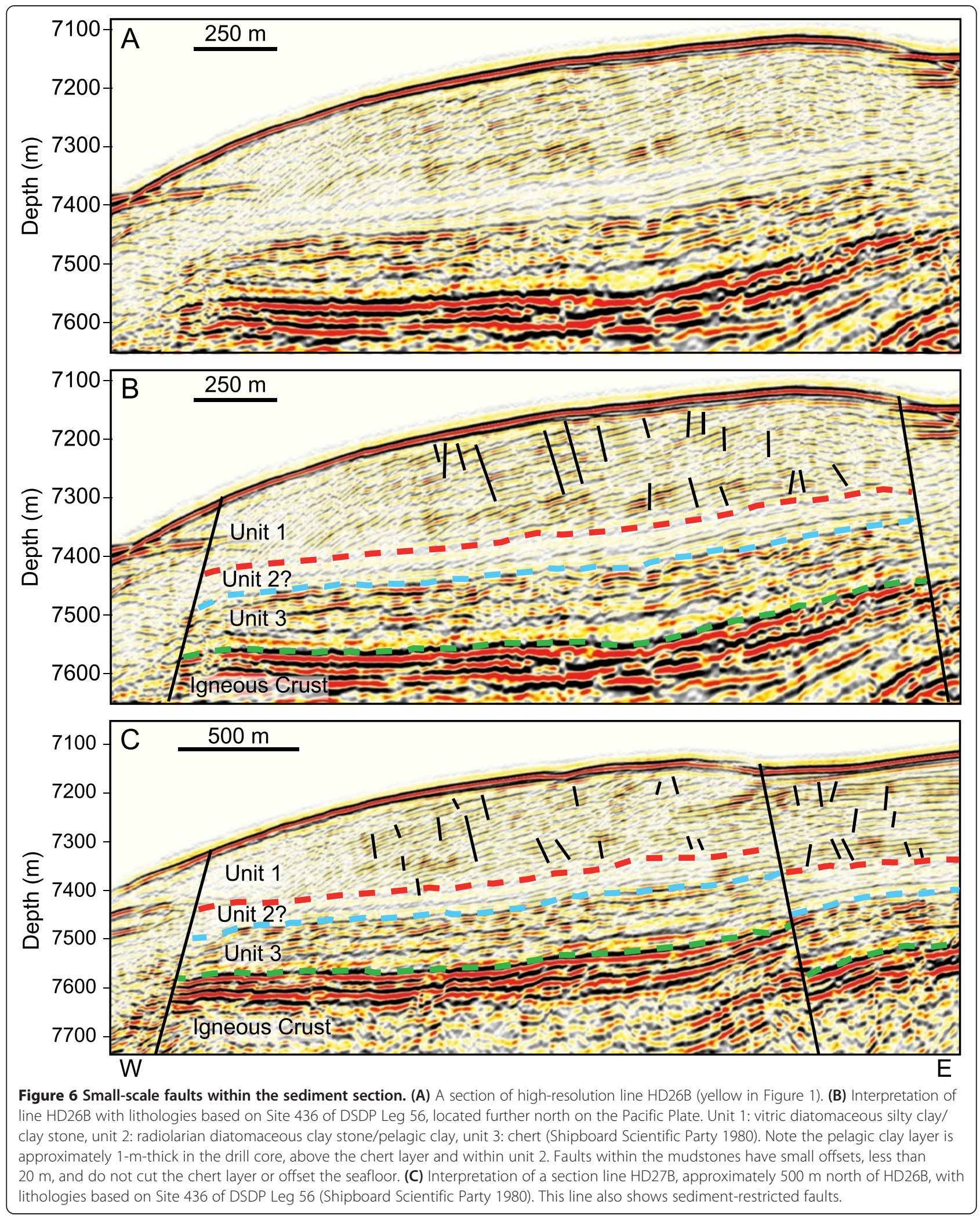




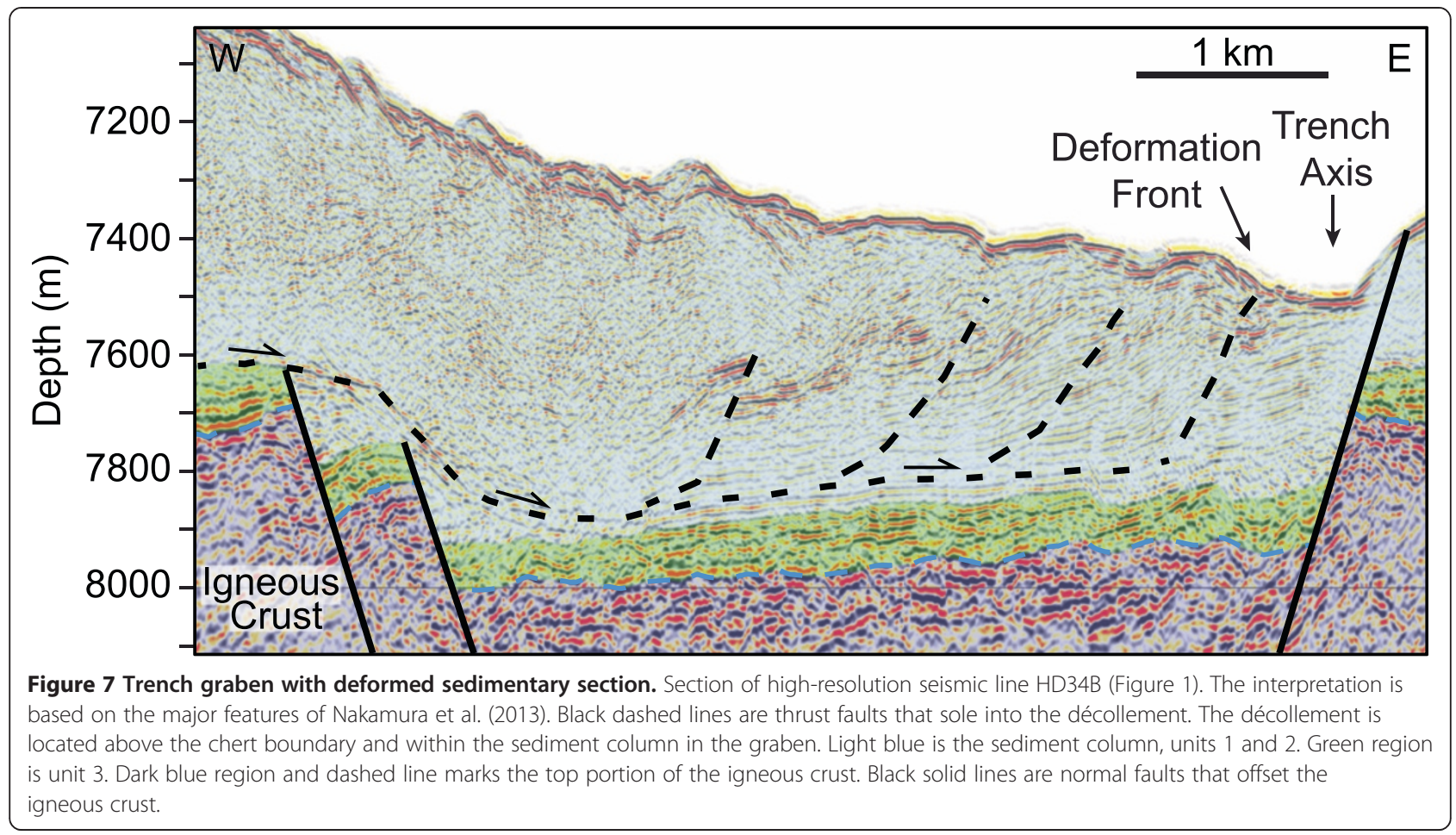

The fault traces in our survey area is similar to patterns developed in other locations and in analog models. Onshore three-dimensional (3D) normal fault propagation through basalt shows linkage of surface fractures that produce a fault with an irregular trace (Kaven and Martel 2007). Similar zig-zag fault traces have been generated in analog fault experiments where different stress directions were applied to the sediments (e.g., Henza et al. 2011). The 3D stress field of the Japan Trench outer rise is poorly known. A bend in the Japan Trench trend at $38^{\circ} \mathrm{N}$ will create 3D effects not accounted for in 2D models. Furthermore, coseismic rupture of thrust segments south and north of $38^{\circ} \mathrm{N}$ will create a heterogeneous stress field on the outer rise. This is the only region along the Japan Trench where topographic structures on the subducting plate lie collinear with the fracture zone strike (Nakanishi 2011). At approximately $30^{\circ}$ from the trend of the northern part of the trench (Figure 1), the fracture zone trend is slightly more than the approximately $25^{\circ}$ reactivation cutoff determined by Billen et al. (2007). However, that study

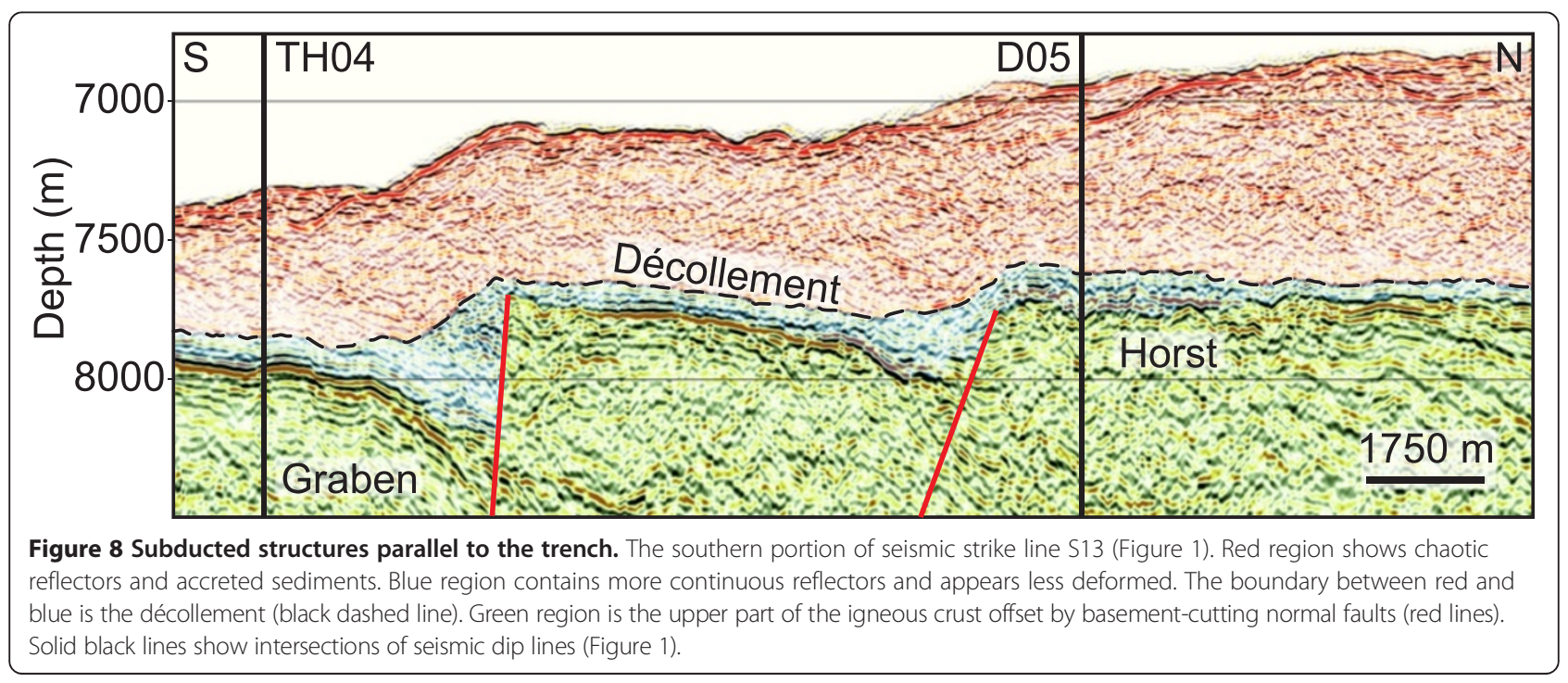




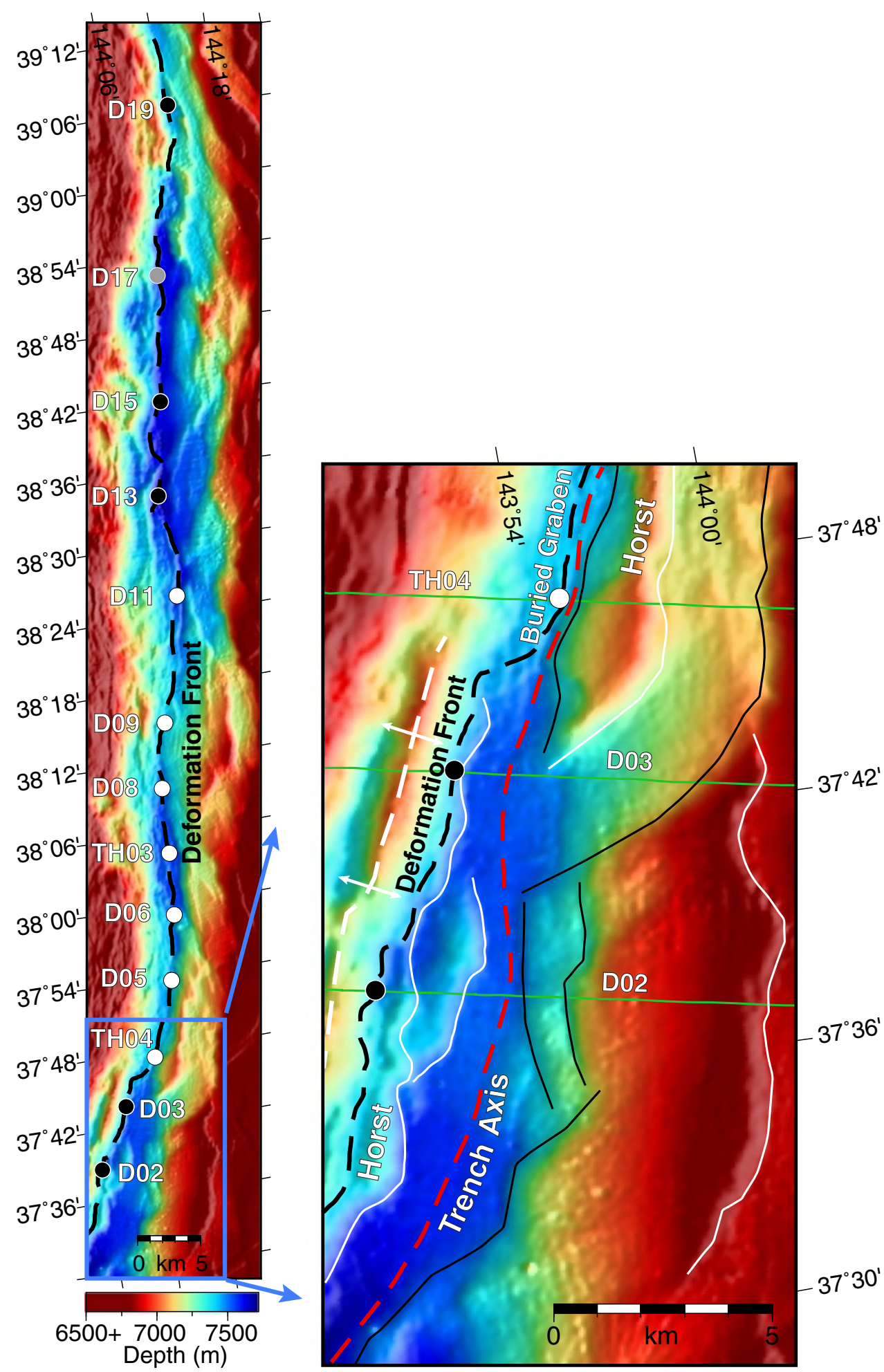

Figure 9 Trench axis bathymetry. The dashed black line marks the deformation front based on seismic and bathymetric interpretations. White and black circles mark the deformation front located above a graben or horst, respectively, whereas a gray dot marks a half-graben. Seismic line numbers (e.g., D02, D03) are plotted near respective circles. Blue box marks location of inlet to the right. White and black solid lines are normal faults dipping seaward and landward, respectively. The trench axis is marked by a red dashed line. The green lines are the location of the seismic lines. The white dashed line is an anticline. The deformation front is not merely following topographic lows but may be reacting to the incoming structures. 
considered only reactivation of abyssal hill trends, but this may still imply that fracture zones are still weak with a lower coefficient of friction than the surrounding rock. Following initial surface breaks parallel to the trench, large fault-tip stress concentrations may help reactivate the pre-existing fabrics to develop the fault trace geometry found in the survey area (Figure 1).

Branches, relays, and conjugate faults are found in many normal fault populations (Peacock 2002; Morley et al. 2007; Nicol et al. 1995; Walsh et al. 1999). The presence of such features in our study area indicates poor lateral fault connectivity. Regional north to south differences in cumulative throw (Figure 4) may be related to such lateral effects. Fault interactions, especially in areas with closely spaced faults, may also contribute to variations in slip distributions along a single fault (Martel and Shacat 2006). Therefore, our throw analysis should be viewed cautiously due to effects of nearby faults and location of our MCS lines within individual fault segments.

\section{Incoming plate sediment thickness}

Sediment thickness and lithology of the incoming plate plays a dominant role in development and growth of accretionary prisms. Accurate understanding of the geometry of the TIC and overlying sediments is vital to measuring sediment influx and fault throw. Although basement-cutting faults offset the TIC, the TIC is not always a continuous, strong reflector in between basement-cutting faults within the study area, as seen on the eastern section of line D02 (Figure 5A). This discontinuous nature of the TIC in our seismic lines is due to several factors: 1) seismic imaging through complex geology scatters ray paths, resulting in an inadequately imaged subsurface. In our study area, this is largely caused by to the rough seafloor and the chert layer overlying the TIC. The high-resolution survey data likely show greater scattering (due to the higher frequency content), as the regional lines image the TIC more consistently. 2) The velocity of the overlying chert creates little impedance contrast with the TIC. Although no formation velocity for DSDP Site 436 was measured for the chert unit, velocities of porcellanite and chert samples generally range from 2.6 to $4.8 \mathrm{~km} / \mathrm{s}$ (Shipboard Scientific Party 1980), which may be near the velocity of the TIC. 3) Drilling at Site 436 did not reach the igneous basement, leaving the composition and alteration of the basement unknown near our survey location. Mineralogic analysis of oceanic basalts elsewhere reveals significant alteration with a large potential for fluid incorporation (Kameda et al. 2011), which may lower the acoustic impedance across the TIC. 4) The igneous basement may differ compositionally throughout the survey area. The seismic character of a sill or sheet flow may produce a smoother and stronger reflector than pillows and flows (Abrams et al. 1993), creating variations in reflector strength for the TIC. 5) Continued faulting along the outer rise will further reduce continuous reflections from the TIC. This can be from development of a new fault breach through the TIC, secondary faulting, or off-fault, nonelastic deformation, including fissure and cavity formation, as the fault tip propagates towards the surface (Holland et al. 2006; Martel and Langley 2006). Even with sections of discontinuous TIC, we are confident in our interpretation because we observe relative amplitude and frequency differences between the sediment and underlying basalt along with regions of a prominent TIC horizon.

Our results reveal variations of as much as $600 \mathrm{~m}$ in thickness of the sediments overlying the TIC (Figure 1B). Correlation of sediment thickness between regional lines was not possible because the seismic line spacing is too wide and there are complications imposed by variation in fault strikes. Basement topography is a dominant factor in variation of sediment thickness in two ways. 1) Older structures contribute to sediment variations. For example, the abyssal hill imaged in line D19 (Figure 2) has thinner sediments above it than on its flanks (Figures 1 and 2). Interpreted petite spot volcanic fields found in the southeast of the survey (Figure 1) have little to no sediment cover owing to their likely young age, based on ages of nearby fields (Hirano et al. 2008). Similarly, sediment overlying the tops of seamounts is generally much thinner than on the seamounts' flanks. 2) Basementcutting normal faults influence sediment thickness. This may be caused by erosion of topographic highs by bottom currents or by mass wasting (Figure 6) and filling of topographic lows, such as along graben systems (Figure 5). Sediment thickness generally increases towards the trench but with fluctuations as large as approximately $400 \mathrm{~m}$ on individual lines. No regional trends in sediment thickness are found in other directions. However, the large grid spacing between regional lines will mask small-scale trends. Because the Japan Trench accretes a large portion of sediment at the toe (Figure 7; Kodaira et al. 2012; Nakamura et al. 2013), sediment variations of $600 \mathrm{~m}$ may still affect prism morphology because they are a large percentage of the total sediment thickness. However, due to the fluctuations in sediment thickness and lack of regional trends, prism morphology and growth in our survey area owing to the incoming sediments is difficult to constrain.

\section{Décollement propagation}

Seismic sections of a near-trench subducting graben (Figure 7; Kodaira et al. 2012; Nakamura et al. 2013) reveal a low-angle, seaward-dipping reflector descending into the graben from the adjacent horst block. Imbricate structures sole into the same plane, which is thus interpreted to be the décollement. The mechanism for this décollement step-down into a local trench graben is poorly understood. Although landslides are a potential mechanism for creating the step-down (Strasser et al. 2013), we propose 
additional mechanisms for the step-down that involves the subduction and burial of an active normal fault (Figure 10). Surface breaching normal faults, like the majority of incoming faults, have a very different stress field than that of buried faults. Large horizontal and vertical tensile stresses occur at the fault tip and footwall of buried faults (Martel and Langley 2006). As the décollement propagates over a breached normal fault, it buries this fault under the prism. We propose the following situations may occur as a result:

1) As a graben passes beneath the near-trench edge of the overriding plate, the tensile stress from the buried normal fault may increase. The stress field of a fault tip breaching the seafloor versus being buried differs drastically (e.g., Martel and Langley 2006). This increase in tensile stress may promote the décollement to step-down into the graben.

2) Subduction of horst-graben structures may be similar to seamount subduction. Coulomb wedge mechanics argues that the change in basement slopes due to subducting a seamount promote both overcritical and undercritical wedge deformation (Lallemand and Le Pichon 1987). For an incoming horst block, the increase in basement slope could promote undercritical wedge deformation and affected by shortening. For an incoming graben, the decrease in the basement slope could promote overcritical deformation within the prism, creating listric faulting or slumps into the graben. There are three morphologic differences between subducting seamounts and normal faults: their vertical scales, slopes, and associated sediment. Seamounts studied near active margins tend to be greater than $16-\mathrm{km}-$ wide and more than $1.5 \mathrm{~km}$ above the seafloor with slopes less than $20^{\circ}$ (Dominguez et al. 1998). They also have significantly less sediment cover than their surroundings. However, horst-graben structures entering the Japan Trench are much smaller, lowerrelief features (average throw of approximately $122 \mathrm{~m}$ and fault spacing of approximately $2 \mathrm{~km}$ ), have steeper flanks (approximately $50^{\circ}$ to $80^{\circ}$ fault dips) and have smaller variations in sediment thickness. The large broad change in both sediment type and thickness, may play an important role for seamount subduction as a mechanically distinctive zone, but the horstgraben lithology varies little. These differences may

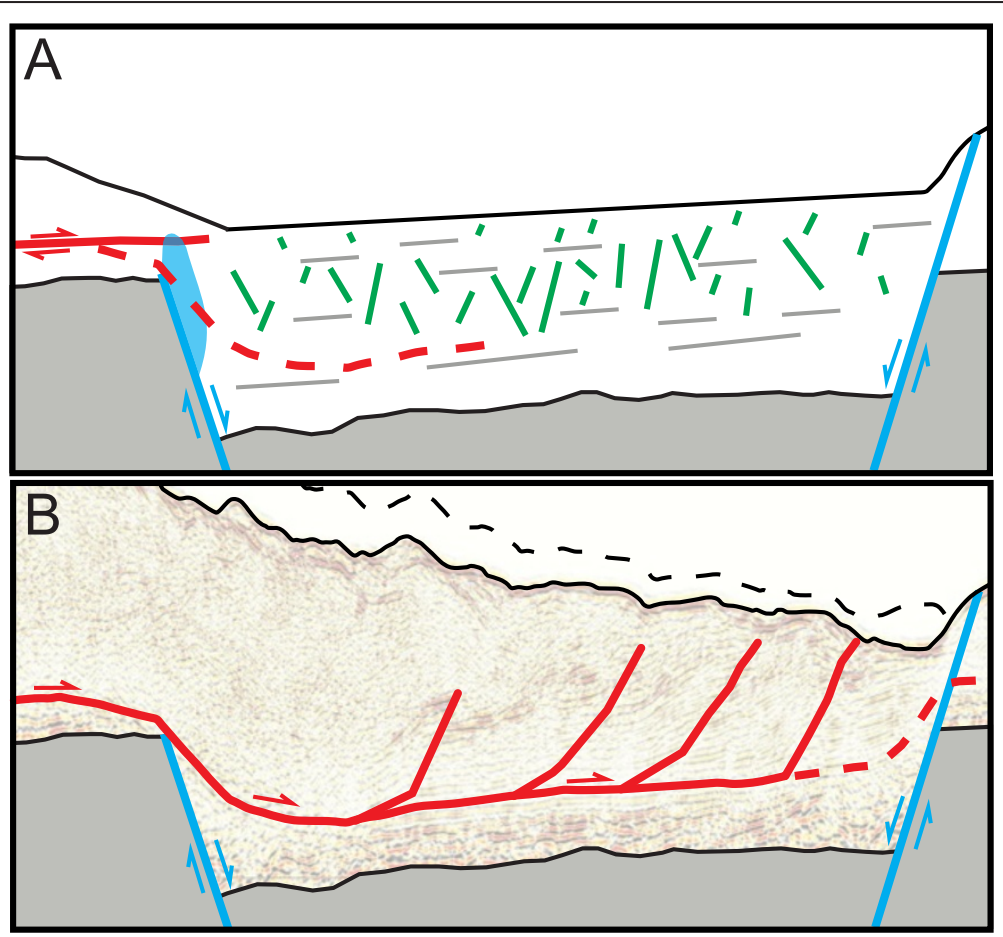

Figure 10 A schematic model for near-trench décollement propagation. Model uses seismic line HD34B (Figure 7) with the western basement-cutting normal faults simplified to just one. (A) Early stages of the décollement step-down into a trench graben. This model is based on two fault tips and their associated tensional stress fields, both of which are found in the trench graben (décollement in red, normal faults in blue, sedimentary faults in green). Blue region is the area of vertical tension based on a 100-m buried normal fault (modified from Martel and Langley, 2006). Red dashed line is the future path of the décollement into the trench graben. (B) The future décollement step-up out of the graben. The red solid line is the current location of the décollement (Figure 7) with the red dashed section being a potential future pathway. The future ramp-up may develop from a frontal thrust. The seafloor will likely steepen (black dashed line) as the wedge advances seaward. 
create a different upper plate deformation for a horstgraben than a seamount.

3) Normal faults restricted to sedimentary units 1 and 2 (Figure 6) may become more active, with increasing offsets, as the plate moves closer to the trench. By breaking through the layered sediments, these sediment-restricted faults could act as a pathway for the décollement step-down from the top of the horst blocks into the adjacent graben.

4) As the décollement propagates seaward, either on top of the graben or within the graben sediments, the buried active basement-cutting normal fault will continue propagating upward, and the décollement will eventually be offset by the basement-cutting fault. These two intersecting faults may continue to offset the fault plane of the other if they remain active. The effects of active normal faults further landward, beneath the prism, are less easily resolved. However, such basement-cutting faults may continue to influence the décollement geometry, as OBS data reveal, they remain active under the prism (Obana et al. 2013).

Horst block subduction also affects the up-dip geometry of the décollement (Kimura et al. 2012) and potentially lateral décollement connectivity. Our regional lines image subducted horsts near the trench and show that the décollement ascends over the subducting horst along a fault ramp (Figure 5B). A seafloor bathymetric high above the ramp is an anticline caused by sediments being folded over the fault bend (Figure 9). Fault slip over this $20^{\circ}$ dipping décollement fault ramp will create greater seafloor uplift than in sections of shallow dips. Furthermore, the sediment column overlying the décollement ramp shows no continuous reflections, thus indicates internal deformation (Figure 5). In the high-resolution lines, the décollement stops within a graben near the incoming horst block (Figure 7). Seafloor topography within this graben deepens to the south. This morphology change can be attributed to varying internal deformation and uplift along strike, in that the décollement propagates seaward to a horst where the prism topography steepens before creating a ramp over the horst. If décollement propagation does vary in horst-graben systems, subduction of intersecting or linked normal fault sections would create lateral décollement segments that are linked at depth.

Faults within the sediment column may play an additional role in décollement propagation. DSDP Site 436 (Figure 1C) is the only nearby site where sediments on the Japan Trench's outer rise have been sampled; drilling there only penetrated to the chert layer (Shipboard Scientific Party 1980). At Site 436, a small layer of pelagic clay overlies the chert. In this deep water setting, the overall lithology is not expected to vary much laterally, allowing for a general correlation among our seismic lines. Ogawa et al. (1997) discovered cracks in the seafloor along the outer rise and proposed that a combination of gravitational slope instability and earthquake shaking for the cracks formation. These surface cracks may be from the early stages of sedimentrestricted normal faulting at depth, imaged in the highresolution survey (Figure 6). These sediment-restricted faults may have a basal sliding plane between the basement-chert, chert-clay boundaries, and/or within the upper unit, deforming the sediment along strata. The creation of these sliding surfaces before subduction may play a role during seismic rupture to the trench. The Japan Trench Fast Drilling Project (Integrated Ocean Drilling Program Expedition 343 and $343 \mathrm{~T}$ ) drilled to the chert layer further landward (Figure 1) and found that the décollement is located within a thin band of pelagic clay (Chester et al. 2012), with localized deformation occurring within $5 \mathrm{~m}$ of this pelagic clay. Thus, this lithological unit may be a regional control on rupture to the trench (Chester et al. 2013), as the low coseismic shear stress and low coseismic friction of the clay may have allowed the 2011 Tohoku earthquake to rupture to the trench (Fulton et al. 2013; Ujiie et al. 2013). However, Expedition 343 drilled only above a horst block. Seismic results agree with the décollement's location above the horst. However, within the graben, the décollement located higher in the sediment column (Figure 7). The pelagic clay within a graben may have a more dominant role in sediment sliding and sediment-restricted faulting (Figure 6) than for décollement propagation. Near-trench faults in sediment may play an important role in weakening the sediment before subduction.

The accretionary prism at the toe of the Japan Trench initially accumulates a major proportion of incoming sediment. Previous models indicated that all of the sediments within a graben were subducted, as the décollement propagated over the top of the entire graben sediment column (e.g., Hilde 1983). This would allow for significant sediment subduction. However, the décollement appears to initially scoop out the majority of sediments within a graben (Figure 7). Furthermore, both seismic and drilling (e.g., Chester et al. 2013) indicate that the décollement is near the base of the sediment column when located above a horst. These results reduce the amount of sediment available for subduction under the toe of the frontal prism. Variations in both the incoming sediment column thickness (Figure 1) and the amount of long-term sediment accretion cause potential difficulties in calculating the amount of sediment subducted (e.g., Clift and Vannucchi 2004). Additionally, instead of underthrust sedimentfilled graben blocks being only vertically loaded, initial sediment accretion may affect overall sediment porosity due to the addition of both vertical and horizontal strains on the subducting sediment (e.g., Moore et al. 2011). This may affect the sediment dehydration further landward 
and, as a result, whether or not subduction erosion might occur at depth. Other water-rich sources may contribute more to the fluid budget including both the igneous basement and chert, where the dehydration range for siliceous sediments starts at approximately $40 \mathrm{~km}$ landward of the Japan Trench (Kimura et al. 2012). Sediment cracks and faults along with basement faults may provide necessary pathways for fluid transport and may play a vital role in hydration below the sediment column. These near-trench processes may influence different subduction processes occurring at depth at the Japan Trench subduction zone.

\section{Conclusions}

Although generally included in discussion of subducting topography (e.g., Bilek 2007), bending-related normal faults are typically not considered to directly deform the overriding plate at the toe of the landward trench slope. Our depth-migrated regional and high-resolution seismic lines that image the incoming Pacific Plate along the Japan Trench off Tohoku show trench-parallel faults that offset the igneous crust on the outer-rise seaward of the trench. As the plate moves landward, reactivation of pre-existing seafloor structures, due to either increasing bending stresses or interaction with trench-parallel faults, further deforms the plate. Throw analysis indicates more offset in the north than south of our survey area with continuing formation of faults towards the trench. Sediment thickness of the Pacific Plate is not uniform but fluctuates between 0 and $600 \mathrm{~m}$ with a general increase in thickness towards the trench. Recent sediment deposits are present in some normal fault footwalls and near-trench topographic lows. Furthermore, the sediment column contains densely spaced fault populations with only a few meters of offset. We expand on previous studies (e.g., Kodaira et al. 2012; Nakamura et al. 2013) to document up-dip décollement propagation over both horst and graben systems along the Japan Trench and found the deformation front located further landward during initial subduction of a horst block compared to graben subduction. We propose a relationship between the décollement seaward propagation and normal faults that reflect stresses and displacements at the tips of actively subducting active normal faults. Other margins where horst blocks are subducting, such as the Middle America Trench off Costa Rica (Moore et al. 1986; Moore and Shipley 1988) should also be considered for anomalous seafloor displacement during coseismic rupture to the trench axis. Furthermore, our results have additional implications for the hydration of the plate and upper mantle (Ranero et al. 2003; Garth and Rietbrock 2014) from both large- and small-scale faulting, prism development (Underwood 2007; Ike et al. 2008), and coseismic near-trench anomalous vertical displacement (e.g., Kodaira et al. 2012). Thus, bending-related normal faults may play an integral role in near-trench subduction zone processes.
Competing interests

The authors declare that they have no competing interests.

\section{Authors' contributions}

BB participated in KR11-E05, carried out the PSDM processing and interpretation, and wrote the manuscript. GM supervised the processing, interpretation, and manuscript preparation. YN was the chief scientist on KY11-E05 and participated in the data interpretation and manuscript preparation. SK planned and organized the project and participated in the data interpretation and manuscript preparation. All authors read and approved the final manuscript.

\section{Acknowledgements}

Funding for this project was through the National Science Foundation (grant numbers OCE-1260718 and OCE-1138051). The authors are grateful to S. Martel, P. Fryer, and C. Conrad for their piercing comments that greatly improved the manuscript. We thank Paradigm Geophysical and Landmark Graphics (Halliburton) for their academic software licenses. The authors would like to thank the scientists and crews of KR11-05 Leg 2, KR11-E03, KR11-E05, and KY11-E05.

\section{Author details}

'Department of Geology and Geophysics, University of Hawai'i at Mānoa, 1680 East-West Road, Honolulu, HI 96822, USA. ${ }^{2}$ Research and Development Center for Earthquake and Tsunami, Japan Agency for Marine-Earth Science and Technology, 3173-25 Showa-machi, Kanazawa-ku, Yokohama 236-0001, Japan.

Received: 28 February 2014 Accepted: 25 September 2014 Published: 28 October 2014

\section{References}

Abrams LJ, Larson RL, Shipley TH, Lancelot Y (1993) Cretaceous volcanic sequences and Jurassic oceanic crust in the East Mariana and Pigafetta basins of the western Pacific. In: Pringle MS, Sager WW, Sliter W, Stein S (eds) The Mesozoic Pacific: geology, tectonics, and volcanism, Geophys Monogr 77. AGU, Washington, D.C., pp 77-101

Apel EV, Bürgmann R, Steblov G, Vasilenko N, King R, Prytkov A (2006) Independent active microplate tectonics of northeast Asia from GPS velocities and block modeling. Geophys Res Lett 33(11), L11303, doi:10.1029/2006gl026077

Argus DF, Gordon RG, DeMets C (2011) Geologically current motion of 56 plates relative to the no-net-rotation reference frame. Geochem Geophys Geosyst 12(11), Q11001, doi:10.1029/2011gc003751

Bilek SL (2007) Influence of subducting topography on earthquake rupture. In: Dixon T, Moore C (eds) The seismogenic zone of subduction thrust faults. Columbia University Press, New York, pp 123-146

Billen M, Cowgill E, Buer $E$ (2007) Determination of fault friction from reactivation of abyssal-hill faults in subduction zones. Geology 35(9):819-822, doi:10.1130/G23847a.1

Bodine JH, Steckler MS, Watts AB (1981) Observations of flexure and the rheology of the oceanic lithosphere. J Geophys Res 86(Nb5):3695-3707, doi:10.1029/ Jb086ib05p03695

Chester FM, Mori JJ, Toczko S, Eguchi N, Expedition 343/343T Scientists (2012) Japan Trench Fast Drilling Project (JFAST). IODP Prel Rept 343/343T, doi:10.2204/iodp.pr.343343T

Chester FM, Rowe C, Ujiie K, Kirkpatrick J, Regalla C, Remitti F, Moore JC, Toy V, Wolfson-Schwehr M, Bose S, Kameda J, Mori JJ, Brodsky EE, Eguchi N, Toczko S, Expedition 343 and 343 T Scientists (2013) Structure and composition of the plate-boundary slip zone for the 2011 Tohoku-Oki earthquake. Science 342(6163):1208-1211, doi:10.1126/science.1243719

Christensen DH, Ruff LJ (1988) Seismic coupling and outer rise earthquakes. J Geophys Res 93(B11):13421-13444, doi:10.1029/JB093iB11p13421

Clift P, Vannucchi P (2004) Controls on tectonic accretion versus erosion in subduction zones: implications for the origin and recycling of the continental crust. Rev Geophys 42(2), RG2001, doi:10.1029/2003rg000127

Costa Pisani P, Reshef M, Moore GF (2005) Targeted 3-D prestack depth imaging at Legs 190-196 ODP drill sites (Nankai Trough, Japan). Geophys Res Lett 32(20), L20309, doi:10.1029/2005GL024191

DeMets C, Gordon RG, Argus DF (2010) Geologically current plate motions. Geophys J Int 181(1):1-80, doi:10.1111/j.1365-246X.2009.04491.x 
Dominguez S, Lallemand SE, Malavieille J, von Huene R (1998) Upper plate deformation associated with seamount subduction. Tectonophysics 293(3):207-224

Faccenda M, Gerya TV, Burlini L (2009) Deep slab hydration induced by bending-related variations in tectonic pressure. Nat Geosci 2(11):790-793, doi:10.1038/Ngeo656

Fujii Y, Satake K, Sakai S, Shinohara M, Kanazawa T (2011) Tsunami source of the 2011 off the Pacific coast of Tohoku earthquake. Earth Planets Space 63(7):815-820, doi:10.5047/Eps.2011.06.010

Fujiwara T, Kodaira S, No T, Kaiho Y, Takahashi N, Kaneda Y (2011) The 2011 Tohoku-Oki earthquake: displacement reaching the trench axis. Science 334(6060):1240, doi:10.1126/science.1211554

Fulton PM, Brodsky EE, Kano Y, Mori J, Chester F, Ishikawa T, Harris RN, Lin W, Eguchi N, Toczko S, Expedition 343, 343 T, and KR13-08 Scientists (2013) Low coseismic friction on the Tohoku-Oki fault determined from temperature measurements. Science 342(6163):1214-1217, doi:10.1126/science.1243641

Garth T, Rietbrock A (2014) Order of magnitude increase in subducted H2O due to hydrated normal faults within the Wadati-Benioff zone. Geology 42(3):207-210, doi:10.1130/g34730.1

Grevemeyer I, Ranero CR, Flueh ER, Kläschen D, Bialas J (2007) Passive and active seismological study of bending-related faulting and mantle serpentinization at the Middle America Trench. Earth Planet Sci Lett 258(3-4):528-542, doi:10.1016/j.epsl.2007.04.013

Groshong RH (2006) 3-D Structural geology: a practical guide to quantitative surface and subsurface map interpretation. Springer, New York

Henza AA, Withjack MO, Schlische RW (2011) How do the properties of a pre-existing normal-fault population influence fault development during a subsequent phase of extension? J Struct Geol 33(9):1312-1324, doi:10.1016/j.jsg.2011.06.010

Hilde TWC (1983) Sediment subduction versus accretion around the Pacific. Tectonophysics 99(2-4):381-397

Hino R, Azuma R, Ito Y, Yamamoto Y, Suzuki K, Tsushima H, Suzuki S, Miyashita M, Tomori T, Arizono M, Tange G (2009) Insight into complex rupturing of the immature bending normal fault in the outer slope of the Japan Trench from aftershocks of the 2005 Sanriku earthquake ( $M w=7.0)$ located by ocean bottom seismometry. Geochem Geophys Geosys 10(7):Q07018, doi:10.1029/2009gc002415

Hirano N, Koppers AAP, Takahashi A, Fujiwara T, Nakanishi M (2008) Seamounts, knolls and petit-spot monogenetic volcanoes on the subducting Pacific Plate. Basin Res 20(4):543-553, doi:10.1111/j.1365-2117.2008.00363.x

Holland M, Urai JL, Martel S (2006) The internal structure of fault zones in basaltic sequences. Earth Planet Sci Lett 248:301-315

Ide S, Baltay A, Beroza GC (2011) Shallow dynamic overshoot and energetic deep rupture in the 2011 Mw 9.0 Tohoku-Oki earthquake. Science 332(6036): 1426-1429, doi:10.1126/science.1207020

Ike T, Moore GF, Kuramoto S, Park J-O, Kaneda Y, Taira A (2008) Variations in sediment thickness and type along the northern Philippine Sea Plate at the Nankai Trough. Isl Arc 17(3):342-357, doi:10.1111/j.1440-1738.2008.00624.X

Ito Y, Tsuji T, Osada Y, Kido M, Inazu D, Hayashi Y, Tsushima H, Hino R, Fujimoto H (2011) Frontal wedge deformation near the source region of the 2011 Tohoku-Oki earthquake. Geophys Res Lett 38(7):L00G05, doi:10.1029/ 2011 gl048355

Iwabuchi Y (2012) Extension rates in the outer slope of Japan Trench derived from precise sea bottom topographies. Zisin 65:9-19, doi:10.4294/zisin.65.9

Iwabuchi Y (2013) Developed tectonic relief and frequency of great earthquakes caused by normal faults in the outer slope of the Japan Trench. Report of Hydrographic and Oceanographic Researches 50:1-24

Kameda J, Yamaguchi A, Saito S, Sakuma H, Kawamura K, Kimura G (2011) A new source of water in seismogenic subduction zones. Geophys Res Lett 38(22), L22306, doi:10.1029/2011 gl048883

Kanamori H (1971) Seismological evidence for a lithospheric normal faulting - the Sanriku earthquake of 1933. Phys Earth Planet Inter 4:289-300

Kaven JO, Martel SJ (2007) Growth of surface-breaching normal faults as a three-dimensional fracturing process. J Struct Geol 29(9):1463-1476, doi:10.1016/J.Jsg.2007.05.007

Kimura G, Hina S, Hamada Y, Kameda J, Tsuji T, Kinoshita M, Yamaguchi A (2012) Runaway slip to the trench due to rupture of highly pressurized megathrust beneath the middle trench slope: the tsunamigenesis of the 2011 Tohoku earthquake off the east coast of northern Japan. Earth Planet Sci Lett 339-340:32-45, doi:10.1016/j.epsl.2012.04.002

Kodaira S, No T, Nakamura Y, Fujiwara T, Kaiho Y, Miura S, Takahashi N, Kaneda Y, Taira A (2012) Coseismic fault rupture at the trench axis during the 2011 Tohoku-Oki earthquake. Nat Geosci 5(9):646-650, doi:10.1038/Ngeo1547
Lallemand S, Le Pichon X (1987) Coulomb wedge model applied to the subduction of seamounts in the Japan Trench. Geology 15(11):1065-1069, doi:10.1130/0091-7613(1987)15<1065:CWMATT>2.0.CO;2

Lay T, Ammon CJ, Kanamori H, Kim MJ, Xue L (2011) Outer trench-slope faulting and the 2011 Mw 9.0 off the Pacific coast of Tohoku earthquake. Earth Planets Space 63(7):713-718, doi:10.5047/eps.2011.05.006

Ludwig WJ, Ewing Jl, Ewing M, Murauchi S, Den N, Asano S, Hotta H, Hayakawa M, Asanuma T, Ichikawa K (1966) Sediments and structure of the Japan Trench. J Geophys Res 71(8):2121-2137

Martel SJ, Langley JS (2006) Propagation of normal faults to the surface in basalt, Koae fault system, Hawaii. J Struct Geol 28(12):2123-2143, doi:10.1016/j. jsg.2005.12.004

Martel SJ, Shacat C (2006) Mechanics and interpretations of fault slip. In: Abercrombie G, Di Toro G, Kanamori H, McGarr A (eds) Radiated energy and the physics of earthquake faulting, Geophys Monogr 170. AGU, Washington, D.C, pp 207-216

Masson DG (1991) Fault patterns at outer trench walls. Mar Geophys Res 13:209-225

McCann WR, Sykes LR (1984) Subduction of aseismic ridges beneath the Caribbean plate: implications for the tectonics and seismic potential of the northeastern Caribbean. J Geophys Res 89:4493-4519

Moore GF, Shipley TH (1988) Behavior of the decollement at the Toe of the Middle America Trench. Geol Rundsch 77:275-284

Moore GF, Shipley TH, Lonsdale PF (1986) Subduction erosion versus sediment offscraping at the toe of the Middle America Trench off Guatemala. Tectonics 5:513-523

Moore GF, Saffer D, Studer M, Costa Pisani P (2011) Structural restoration of thrusts at the toe of the Nankai Trough accretionary prism off Shikoku Island, Japan: implications for dewatering processes. Geochem Geophys Geosyst 12(5):Q0AD12, doi:10.1029/2010gc003453

Morley CK, Gabdi S, Seusutthiya K (2007) Fault superimposition and linkage resulting from stress changes during rifting: examples from 3D seismic data, Phitsanulok Basin, Thailand. J Struct Geol 29(4):646-663, doi:10.1016/j.jsg.2006.11.005

Nakamura Y, Kodaira S, Miura S, Regalla C, Takahashi N (2013) High-resolution seismic imaging in the Japan Trench axis area off Miyagi, northeastern Japan. Geophys Res Lett 40(9):1713-1718, doi:10.1002/grl.50364

Nakanishi M (2011) Bending-related topographic structures of the subducting plate in the northwestern Pacific Ocean: accretionary prisms and convergent margin tectonics in the northwest Pacific basin. In: Ogawa Y, Anma R, Dilek Y (eds) Modern Approaches in Solid Earth Sciences, vol 8. Springer, Netherlands, pp 1-38

Naliboff JB, Billen MI, Gerya T, Saunders J (2013) Dynamics of outer-rise faulting in oceanic-continental subduction systems. Geochem Geophys Geosyst 14(7):2310-2327, doi:10.1002/ggge.20155

Nicol A, Walsh JJ, Watterson J, Bretan PG (1995) Three-dimensional geometry and growth of conjugate normal faults. J Struct Geol 17(6):847-862, doi:10.1016/ 0191-8141(94)00109-D

Niitsuma N (2004) Japan Trench and tectonics of the Japanese Island Arcs. Is| Arc 13(1):306-317, doi:10.1111/J.1440-1738.2003.00427.X

Obana K, Fujie G, Takahashi T, Yamamoto Y, Nakamura Y, Kodaira S, Takahashi N, Kaneda Y, Shinohara M (2012) Normal-faulting earthquakes beneath the outer slope of the Japan Trench after the 2011 Tohoku earthquake: implications for the stress regime in the incoming Pacific plate. Geophys Res Lett 39(7):L00G24, doi:10.1029/2011gl050399

Obana K, Kodaira S, Shinohara M, Hino R, Uehira K, Shiobara H, Nakahigashi K, Yamada T, Sugioka H, Ito A, Nakamura Y, Miura S, No T, Takahashi N (2013) Aftershocks near the updip end of the 2011 Tohoku-Oki earthquake. Earth Planet Sci Lett 382:111-116, doi:10.1016/j.epsl.2013.09.007

Obana K, Kodaira S, Nakamura Y, Sato T, Fujie G, Takahashi T, Yamamoto Y (2014) Aftershocks of the December 7, 2012 intraplate doublet near the Japan Trench axis. Earth Planets Space 66:24, doi:10.1186/1880-5981-66-24

Ogawa Y, Kobayashi K, Hotta H, Fujioka K (1997) Tension cracks on the oceanward slopes of the northern Japan and Mariana Trenches. Mar Geol 141(1-4):111-123, doi:10.1016/S0025-3227(97)00059-5

Peacock DCP (2002) Propagation, interaction and linkage in normal fault systems. Earth-Sci Rev 58(1-2):121-142, doi:10.1016/S0012-8252(01)00085-X

Ranero CR, Morgan JP, Mclntosh K, Reichert C (2003) Bending-related faulting and mantle serpentinization at the Middle America Trench. Nature 425(6956):367-373, doi:10.1038/Nature01961

Sato T, Hiratsuka S, Mori J (2013) Coulomb stress change for the normal-fault aftershocks triggered near the Japan Trench by the 2011 Mw 9.0 Tohoku-Oki earthquake. Earth Planets Space 64(12):1239-1243, doi:10.5047/eps.2012.04.003 
Shipboard Scientific Party (1980) Site 436: Japan Trench outer rise, Leg 56. In: Initial reports of the Deep Sea Drilling Project, vol 56, 57, Pt. 1. U.S. Govt. Printing Office, Washington, pp 399-446, doi:10.2973/dsdp.proc.5657.107 Strasser M, Kolling M, dos Santos FC, Fink HG, Fujiwara T, Henkel S, Ikehara K, Kanamatsu T, Kawamura K, Kodaira S, Romer M, Wefer G, RN Sonne Cruise SO219A, JAMSTEC Cruise MR12-E01 Scientists (2013) A slump in the trench: tracking the impact of the 2011 Tohoku-Oki earthquake. Geology 41 (8):935-938, doi:10.1130/G34477.1

Taylor FW, Mann P, Bevis MG, Edwards RL, Cheng H, Cutler KB, Gray SC, Burr GS, Beck JW, Phillips DA, Cabioch G, Recy J (2005) Rapid forearc uplift and subsidence caused by impinging bathymetric features: examples from the New Hebrides and Solomon arcs. Tectonics 24(6), TC6005, doi:10.1029/ 2004tc001650

Tsuru T, Park JO, Takahashi N, Kodaira S, Kido Y, Kaneda Y, Kono Y (2000) Tectonic features of the Japan Trench convergent margin off Sanriku, northeastern Japan, revealed by multichannel seismic reflection data. J Geophys Res 105(B7):16403-16413, doi:10.1029/2000jb900132

Ujiie K, Tanaka H, Saito T, Tsutsumi A, Mori JJ, Kameda J, Brodsky EE, Chester FM, Eguchi N, Toczko S, Expedition 343 and 343 T Scientists (2013) Low coseismic shear stress on the Tohoku-Oki megathrust determined from laboratory experiments. Science 342(6163):1211-1214, doi:10.1126/science.1243485

Underwood MB (2007) Sediment inputs to subduction zones: why lithostratigraphy and clay mineralogy matter. In: Dixon TH, Moore JC (eds) The Seismogenic Zone of Subduction Thrust Faults. Columbia University Press, New York, pp 42-85

von Huene R, Culotta R (1989) Tectonic erosion at the front of the Japan Trench convergent margin. Tectonophysics 160(1):75-90

von Huene R, Ranero CR, Vannucchi P (2004) Generic model of subduction erosion. Geology 32(10):913-916, doi:10.1130/g20563.1

Walsh JJ, Watterson J, Bailey WR, Childs C (1999) Fault relays, bends and branchlines. J Struct Geol 21(8):1019-1026

Yilmaz O (2001) Seismic data analysis: processing, inversion, and interpretation of seismic data. SEG, Tulsa, OK

doi:10.1186/1880-5981-66-135

Cite this article as: Boston et al:: Outer-rise normal fault development and influence on near-trench décollement propagation along the Japan Trench, off Tohoku. Earth, Planets and Space 2014 66:135.

\section{Submit your manuscript to a SpringerOpen ${ }^{\circ}$ journal and benefit from:}

- Convenient online submission

- Rigorous peer review

- Immediate publication on acceptance

- Open access: articles freely available online

- High visibility within the field

- Retaining the copyright to your article

Submit your next manuscript at $\gg$ springeropen.com 